\title{
PAMIĘĆ POLITYCZNA I POLITYKA PAMIĘCI W TEORII I PRAKTYCE SYMBOLICZNEJ DOMINACJI ELIT POSTRADZIECKICH
}

ABSTRACT Political memory and politics of memory in theory and practice of symbolic domination post-soviet elites

The article discusses methodological opportunities for conceptualization of political memory through correlation with symbolic structure of political communication. The author argues that the structure of political expectations of political memory carries out function of symbolic designing of political communication. The analysis of temporal structure of political expectations is especially important for understanding designing of „Politics of Memory” in post-soviet spaces.

Keywords: political memory, political expectations, political legitimating, politics of memory, symbolic politics

Słowa kluczowe: pamięć polityczna, oczekiwania polityczne, legitymizacja polityczna, polityka pamięci, polityka symboliczna 
Swego czasu Jean-Paul Sartre, rozważając motywy wyborów człowieka, słowami bo$\checkmark$ haterów jednej ze swoich sztuk zauważył, że Kiedy Bóg milczy, można mu wtożyć w usta wszystko, co się chce ${ }^{1}$. Zniknięcie Związku Radzieckiego z mapy politycznej doprowadziło do zniszczenia „panteonu bogów socjalistycznych” i pojawienia się nowych państw i przekonań ideologicznych. Niektóre z nich sprzyjały społecznemu konstruowaniu tożsamości narodowej i dokonywanym wyborom politycznym. Równocześnie poszerzenie horyzontów indywidualnego wyboru w przypadku obywateli wielu państw postradzieckich nie doprowadziło do ukształtowania stabilnej tożsamości politycznej, nie zwiększyło poziomu odpowiedzialności obywatelskiej jednostek i legitymizacji nowych elit politycznych.

Powstała po ideologicznej dekonstrukcji radzieckiej kultury politycznej „dziura semantyczna o wielkości tego, co radzieckie”, chociaż zapełniła się mnogością ideologicznych opisów istniejącego porządku społecznego, to wciąż jednak pozostaje źródłem zakłóceń i konfliktów w komunikacji politycznej współczesnej Rosji i byłych republik Związku Radzieckiego. Problemy związane z demokratyczną ewolucją rosyjskiego społeczeństwa uwarunkowane są przez proces ideologicznej delegalizacji wzorców kultury radzieckiej, brak równowagi w polityczno-kulturowych praktykach legitymizacji i delegitymizacji porządku politycznego. W odniesieniu do Rosji oznacza to blokowanie procesu ewolucyjnego konstruowania wzorców teraźniejszości na materiale niedawnej przeszłości i destrukcyjną, pełną zagrożeń samowolę polityki symbolicznej, prowadzonej przez elity intelektualne i polityczne. Jeśli dla przestrzeni kulturowych krajów Układu Warszawskiego „radzieckość” stanowiła peryferyjny koncept ideologiczny, to dla przestrzeni ZSRR była rezerwuarem istotnych społecznie sensów i ukrytych wzorów, schematów poznawczych zakorzenionych w życiu codziennym. Zjawiska te związane są również z problemami teoretyczno-metodologicznymi i błędami popełnianymi przez elity intelektualne i konsultantów politycznych przy interpretowaniu roli i miejsca praktyk politycznych i kulturowych niedawnej przeszłości w społecznym konstruowaniu tożsamości politycznej rosyjskiej teraźniejszości.

W związku z tym celowe wydaje się zbadanie legitymizującej roli symbolicznego dziedzictwa „przeszłości” w teraźniejszości z użyciem metodologicznego instrumentarium analizy struktur czasowo-przestrzennych pamięci społecznej, determinujących dynamikę, ukierunkowanie sposobów opisu i uzasadnianie rzeczywistości społecznej. Strategia tego rodzaju pozwala na zmniejszenie potencjału normatywnego i aksjologicznego tradycyjnych interpretacji kultury przy opisie jej wpływu na procesy zachodzące we współczesnym społeczeństwie.

Badania pamięci „społecznej”, „kulturowej”, „historycznej” i „politycznej” są dość dobrze reprezentowane w dyskursie socjologicznym, w naukach historycznych i politycznych w ciągu ostatnich dwóch dekad. Dyskurs ten oparty jest na długiej tradycji refleksji nad „pamięcią” jako podstawowym sposobem istnienia człowieka, podejmo-

Ж.-П. Сартр, Аьявол и Господь Бог, [w:] tenże, Мертввье без погребения. Аьявол и Господь Бог, Москва 2015, s. 130-146. Cytat wg wydania polskiego: J.-P. Sartre, Diabet i Pan Bóg, przeł. J. Kott, „Dialog” 1959, nr 9, s. 35 . 
wanej przez filozofię polityczną i filozofię kultury, socjologię i psychologię społeczną. Komunikacyjny i kulturowy potencjał ewolucji współczesnych instytucji politycznych w dużej mierze zależy od wpływu schematów znaczeniowych, modeli kognitywnych, pojawiających się w środowiskach intelektualistów i w grupach społecznych, od badania natury ich oddziaływania na treści i kierunki instytucjonalizacji i komunikacji społecznej w ogóle.

Bogate $\mathrm{w}$ treści opracowania i praktyka wykorzystania aparatu kategorialnego, związanego z analizą wpływu doświadczenia przeszłości historycznej na teraźniejszość, sposobów rozumienia politycznej przyczynowości i ich przetworzenie na dyskursy ideologiczne oraz praktyki instytucjonalne zawsze stanowiły ważne ogniwo w opisie, uzasadnieniu i prognozowaniu ewolucji modernizujących się społeczeństw. Swego czasu Karol Marks w dziele 18 brumaire'a Ludwika Bonaparte zaakcentował rolę procedur wskrzeszania „zmarłych”, rolę „duchów przeszłości” oraz zapożyczania ich „szat”, symboli przez „wyobraźnię” do rozwiązywania praktycznych problemów teraźniejszości, przezwyciężenia nieokreśloności i stworzenia „poezji” przyszłości, jej nowego języka². Nie mniej istotne okazały się koncepcje Maxa Webera dotyczące roli i wpływu na „teraźniejszość" różnorodnych historycznych praktyk legitymizacji porządku społecznego w ewolucji gospodarczej i politycznej społeczeństw. „Opisy” struktur pamięci politycznej są niezbędne do badania i społecznego konstruowania komunikacji, gdy sytuacja zostaje rozpoznana jako powtórzenie innej, bez czego nie jest możliwa kontynuacja procesu komunikacyjnego ${ }^{3}$.

Konceptualizacja fenomenu „pamięci politycznej” jest związana nie tylko z klasycznymi problemami epistemologicznego wymiaru zjawisk kulturowych i stopnia ich wpływu na proces polityczny. Nowy impuls tego rodzaju badaniom dały transformacje polityczne i ideologiczne przestrzeni postradzieckiej, koncentrując je na badaniu praktyk symbolicznych i procesu legitymizacji politycznej współczesnych form pamięci społecznej: „polityki pamięci”, „polityki tożsamości”, „upolitycznienia historii” i "polityki historycznej”. Poszukiwanie podstaw ideologicznych „wspólnej pamięci” i odwoływanie się do ofiar złożonych na „ołtarzu ojczyzny” przez rzeczywistych i mitycznych „praojców narodu” stały się toposem retoryki politycznej elit postsocjalistycznych. Permanentne i tragiczne w skutkach próby „rozstawania się” z przeszłością, tak charakterystyczne dla dynamiki socjokulturowej drugiej połowy XX w., wygenerowały dosyć różnokierunkowy pod względem orientacji znaczeniowej „dyskurs pamięci”, epistemologiczną różnorodność naukowych sposobów jego obserwacji i różne przejawy w praktyce politycznej. Proces kształtowania „pamięci politycznej” przy takim sposobie badań jawi się jako różnorodność „polityk symbolicznych”, „polityk tożsamości” $\mathrm{w}$ warunkach obfitującego w konflikty i brzemiennego wybuchami przemocy politycznej przejścia autorytarnych społeczeństw do demokracji.

К. Маркс, 18 бргора Ауи Бонапарта, [w:] К. Маркс, Ф. Энгельс, Сочинения, t. 16, Москва 1960, s. 374-376.

3 Н. Ауман, Эволюиия, Москва 2005, s. 104; Н. Ауман, Введение в системную теорию, Москва 2007, s. 107. 
Naukowa aktualność podjęcia problemu pamięci politycznej, wymiarów czasowych polityki symbolicznej jest uwarunkowana także faktem, że komunikacyjna rzeczywistość współczesnego świata znacznie się zmieniła i nie wpisuje się dłużej w tradycyjne sposoby opisu konstruowania symbolicznego i legitymizacji politycznej. Jest to częściowo wynikiem pomnożenia tożsamości hybrydowych, które pojawiają się, z jednej strony, pod wpływem nowych kodów symbolicznych i struktur sieciowych globalizującego się społeczeństwa, a $\mathrm{z}$ drugiej - $\mathrm{w}$ wyniku oporu wobec ich wpływu socjokulturowego na poziomie narodowym i lokalnym. To decyduje o aktualności problemu opisu dynamiki czasowej nowych "mobilności” społecznych i ich symbolicznych reprezentacji, które zależą od „czynnika czasu”, od cech swoistych „różnych systemów czasu”, co sprawia, że czas staje się „centralnym ogniwem analizy” w ramach tworzącej się „przekształconej” socjologii interdyscyplinarnej ${ }^{4}$. Co charakterystyczne, uznany teoretyk globalizacji Manuel Castells, uzasadniając swoją ontologię społeczną, w ślad za Lévi-Straussem, podkreślił, że powstawanie „społeczeństwa sieciowego” (network society) prowadzi do dominacji morfologii spotecznej nad dziataniem spotecznym. Znamienne, że zadania kultury Castells upatruje w konsolidacji wspólnych znaczeń poprzez krystalizację praktyk w konfiguracjach czasoprzestrzennych5

Równocześnie istniejące konceptualizacje naukowe fenomenu „pamięci politycznej” i rozszerzenie przestrzeni „badań pamięci”, praktyk politycznych jej konstruowania w społeczeństwie są semantycznie i metodologicznie rozmyte. Okresowo pojawiająca się chęć wykorzystania pojęcia „pamięci społecznej” we współczesnych badaniach interdyscyplinarnych i w dyskursie publicznym prowadzi do dużej zmienności treści towarzyszących mu konceptów („pamięć polityczna” i „polityka pamięci”) we współczesnej socjologii, historii i naukach politycznych. Pojęcie „pamięci społecznej” może być wykorzystane jako metafora przy charakterystyce kulturowo-historycznych czynników interakcji społecznych lub wiązane z konkretną metodą badania „ram społecznych” takich interakcji, albo może pretendować do roli nowego instrumentarium kategorialnego w badaniach współczesnych praktyk komunikacyjnych w teorii socjologicznej i historycznej.

Można się zgodzić z Teunem A. van Dijkiem, że chociaż ogólna struktura pamięci społecznej nie jest dotychczas znana, to badanie pamięci społeczno-politycznej jest możliwe jako dociekanie procesu konstruowania na podstawie wiedzy, postaw, ideologii, norm, modeli poznawczych ${ }^{6}$. Procesy poznawcze i procesy reprezentacji, jak zauważa holenderski badacz, zostają określone w odniesieniu do abstrakcyjnej struktury mentalnej, którą określa mianem „memor” i opisuje jako pamięć „krótkotrwałą”

Por. А. Урри, Социология за пределами обществ: видь мобильности для ХХІ столетия, Москва 2012, s. 154-157.

5 Por. M. Castells, Materials for an exploratory theory of network society, „British Journal of Sociology” 2000, Vol. 51, nr 1, s. 5-24.

6 Т. А. Аейк, Аискурс и власть: Репрезентация доминирования в языке и коммуникации, przekład $\mathrm{z}$ ang., Москва 2013, s. 208, 215.

T. A. van Dijk pisze: Cognitive processes and representations are defined relative to an abstract mental structure called „memor”. T. A. van Dijk, Discourse and Power, New York 2008, s. 159 [przypis Redakcji]. 
i „długotrwałą”. Pamięć długotrwałą z kolei dzieli na epizodyczną i semantyczną (społeczną) $)^{8}$. Informacja w pamięci społecznej jest zorganizowana na podstawie reprezentacji mentalnych (struktur mentalnych). Podmioty w wyniku dynamiki tych struktur rodzą modele zdarzeń i działań (modele zdarzeniowe), określające treść znaczeń dyskursów i zapewniające związek oraz synchronizację pamięci krótkotrwałej (osobowej) i społecznej. Tego rodzaju propozycje teoretyczne wymagają jednak uszczegółowienia, ponieważ, jak zauważa holenderski badacz, w interpretacji struktur pamięci społecznej opiera się on na kategorialnym aparacie psychologii, opisując modele działania jako reprezentacje subiektywno-ocenne (subiektywne cechy poznania politycznego), zdeterminowane przez środowisko kulturowe stanowiące podstawę komunikacji i interakcji w społeczeństwie. Prowadzi to, naszym zdaniem, do redukcji teoretycznej, ponieważ struktury pamięci społecznej i politycznej opisywane są jako zmienne zależne od wymiaru przestrzennego lub subiektywnie przeżywanego doświadczenia realizacji decyzji politycznych.

Symptomatyczna jest sytuacja teoretyczno-metodologiczna w jednym z intensywnie rozwijających się pól badań nad pamięcią społeczną - mianowicie analiza sfery „pamięci historycznej”, jako najważniejszego wymiaru indywidualnej i zbiorowej pamięci społecznej i politycznej ${ }^{9}$. Kognitywną podstawą badań pamięci historycznej, z reguły, jest rozróżnienie świadomości historycznej i pamięci historycznej, dyskursu historii i dyskursu pamięci, tożsamości. Znamienne jest stanowisko metodologiczne słynnego francuskiego badacza „miejsc pamięci” Pierre’a Nory. Zauważa on, że krytyczny dyskurs historii niszczy „historię-pamięć”, a zainteresowanie współczesnego społeczeństwa „pamięcią" i „miejscami pamięci” w istocie jest swego rodzaju „chorobą”, która towarzyszy „poszukiwaniu historii”: [...] w sercu-historii dziata destrukcyjny krytycyzm, skierowany przeciw pamięci spontanicznej. Pamięć jest zawsze podejrzana dla historii, której prawdziwa misja polega na tym, aby ja zniszczyć i wyprzeć. Historia jest delegitymizacja przeżytej przesztości $i^{10}$.

U podstaw refleksji o naturze „pamięci społecznej” znanego amerykańskiego przedstawiciela epistemologii historycznej Allana Megilla leży analogiczny, choć nieco złagodzony schemat metodologiczny - „historia versus pamięć”. Empiryczny sens pamięci, jak sugeruje badacz, polega na oznaczaniu i werbalizacji doświadczenia uczestnictwa w wydarzeniach historycznych: Pamięć to obraz przesztości, subiektywnie skonstruowany $w$ teraźniejszości, dlatego [...] jest ona [...] subiektywna; może także być irracjonalna, niekonsekwentna, zwodnicza i samowystarczalna. Pamięć jest zwiq-

Т. А. Аейк, Аискурс и власть..., s. 197-200.

9 Por. пр.: А. П. Репина, Культурная память и проблемь историописания, Москва 2003; А. П. Репина, Концепции сочиальной памяти в современной историографии, [w:] Феномен прошлого, red. И. М. Савельева, А. В. Полетаев, Москва 2005, s. 122-169; История и память: историческая культура Европь до начала Нового времени, red. А. П. Репиной, Москва 2006; И. М. Савельева, А. В. Полетаев, Знание о прошлом: теория и история, t. 2, Сапкт-Петербург 2006, s. 392-471.

10 П. Нора, Между памятью и историей. Проблематика мест памяти, [w:] П. Нора i in., Франция-память, Санкт-Петербург 1999, s. 20-21. 
zana z niepewnościa dzisiejszej tożsamości, konstruującej te wspomnienia, towarzysząca jej nostalgia jest zwiazana z odczuciem usatysfakcjonowania tożsamościa teraźniejszości, rodzącej tę nostalgię. [...] Między historią i pamięcia - uważa Megill - pozostaje granica, która od czasu do czasu można przekroczyć, ale której nikt nie może i nie powinien chcieć usunąíc ${ }^{11}$.

Najbardziej obiecujące dla badań historyczno-kulturowych nad strukturami czasowymi polityki symbolicznej i dla opracowania teorii pamięci politycznej jako swego rodzaju teorii „poziomu pośredniego” (теория „промежуточного уровня”) są, naszym zdaniem, tezy metodologiczne przedstawione w modelach pamięci społecznej niemieckich badaczy Jana i Aleidy Assmannów, a także badaczy podzielających ich naukowe intencje. W tej epistemologii pamięć społeczna nie jest przeciwstawiana świadomości historycznej, kulturze i polityce, ponieważ jest rozpatrywana jako wyjściowy parametr antropologiczny komunikacji kulturowej. Podejście Assmannów jest wynikiem interdyscyplinarnej syntezy badań nad pamięcią społeczną w antropologicznie zorientowanej historii, w strukturalizmie i w teorii komunikacji socjokulturowej. Pozwala to połączyć ogólne socjologiczne założenia procesu komunikacji z teorią analizy dyskursywnej i rekonstrukcją historyczną symbolicznych praktyk dominacji politycznej.

Nie uwzględniając ściśle wszystkich teoretycznych założeń Jana i Aleidy Assmannów, zatrzymamy się na tych istotnych aspektach ich prac, które wydają się nam najważniejsze dla opracowania instrumentarium metodologicznego do analizy temporalnych wymiarów pamięci politycznej i dyskursywnej analizy treści polityki symbolicznej. W interpretacji Jana Assmanna pamięć społeczna, kulturowa to zapewniający tożsamość kompleks wiedzy, znaczeń zobiektywizowanych w formach symbolicznych $^{12}$. W tej epistemologii ramy temporalne pamięci społecznej są traktowane jako autonomiczny parametr symboliczny komunikacji kulturowej. W związku z tym charakterystyczne jest jego stwierdzenie, że synteza czasu i tożsamości dokonuje sięza pośrednictwem pamięci ${ }^{13}$. Zauważa przy tym, że pojęcie pamięci to nie metafora, lecz metonimia, ukierunkowana na odkrycie i artykulację związku tożsamości i czasu, gdzie pamięć jawi się jako swoista struktura temporalna, determinująca swoistość relacji tożsamości i czasu, symbolicznego związku pomiędzy wspominającym rozumem i przypominającymi obiektami ${ }^{14}$. Każde „wspominanie”, jak stale podkreśla w swoich pracach J. Assmann, to przede wszystkim akt semiotyzacji i symbolizacji.

Podobny związek czasu, tożsamości i pamięci, idąc tropem teoretycznych intencji niemieckich badaczy, można opisać w trzech płaszczyznach czasowych: indywidualnej, społecznej i kulturowej, gdzie „pamięć kulturowa” to wariant idealnej instytucji

\footnotetext{
11 А. Мегим, Историческал эпистемология, Москва 2007, s. 124, 147-148.

12 Pог. Я. Ассманн, Культурная памлть: Письмо, память о проилом и политическая идентичность в выссоких культурах древности, przeł. М. М. Сокольской, Москва 2004, s. 16, 64, 71, 82.

13 J. Assmann, Communicative and Cultural Memory, [w:] Cultural Memory Studies: An International and Interdisciplinary Handbook, red. A. Erll, A. Nünning, S. B. Young, Berlin-New York 2010, s. 109.

14 J. Assmann, Communicative and Cultural Memory..., s. 109-110.
} 
prezentacji, kompleks instytucji mnemonicznych i specyficznych form symbolicznych ich obiektywizacji, co zapewnia jej względną dtugotrwatośs $c^{15}$. Tego rodzaju obiektywizacja zostaje zapewniona dzięki symbolicznemu utrwaleniu „punktów” w czasie. Opisując dynamikę pamięci pod względem jakości jej ustrukturyzowania jako gromadząca (mniej ustrukturyzowaną i spontaniczną) oraz funkcjonalną (uzasadniającą teraźniejszość na podstawie konkretnej przeszłości), Aleida i Jan Assmannowie traktują tę ostatnią jako podstawę kształtowania tożsamości politycznych i polityki symbolicznej.

Realizując funkcje legitymacji lub delegitymizacji poprzez wsparcie dynamicznej równowagi we wspomnieniach podmiotów władzy i podwładnych, pamięć funkcjonalna generuje formy pamięci politycznej, tworząc specjalne tożsamości (etnopolityczne, narodowe) i symboliczną politykę zachowania pamięci ${ }^{16}$.

Pamięć narodowa jako historyczna modyfikacja pamięci politycznej to najskuteczniejszy sposób podtrzymania i rekonstrukcji semantycznie znaczącej przeszłości dzięki swojej strukturze czasowej, która zapewnia dużą rozciagtość w czasie, odgrywa główną rolę w legitymizacji instytucji politycznych i konstruowaniu tożsamości politycznej poprzez symbolizację wydarzeń eksponujących heroizm i poświęcenie ${ }^{17}$.

Aleida Assmann, czyniąc punktem wyjścia teoretyczne intencje Jana Assmanna o pamięci kulturowej jako instytucji mnemonicznej, interpretuje pamięć społeczną jako kulturowy, znaczeniowy horyzont, który stanowi swego rodzaju plastyczna wtadze, filtr, kontrolujący wybór tego, jakie wydarzenia społeczne są życiowo ważne, a co podlega zapomnieniu i wyparciu na peryferie. Właśnie ów „horyzont” określa pojawienie się i swoistość tożsamości społecznych, powstanie stabilnych relacji między pamięcią indywidualną i pamięcią grupy ${ }^{18}$.

$\mathrm{Na}$ podstawie tych przesłanek teoretycznych Aleida Assmann wprowadza pojęcie czasowego systemu kultury, według niej oznaczające czasowa organizacje i orientację zakorzenione w kulturze, stanowiące podstawę dla powstania schematów poznawczych współoddziaływań zbiorowych ${ }^{19}$. Swoistość systemu czasowego Nowożytności, dla którego charakterystyczna jest strukturyzacja wydarzeń ze stanowiska teraźniejszości, opisuje jako: czas rozdarcia, fikcyjny nowy początek, twórczą destrukcje, pojawienie się pojęcia „historyczności”, przyspieszenie i opiera się (co symptomatyczne) na analizie semantycznej wyłożonej w ramach niemieckiej szkoły „historii pojęć” Reinharta

15 Por. J. Assmann, Communicative and Cultural Memory..., s. 109-118; A. Assmann, Canon and Archive, [w:] Cultural Memory Studies..., s. 97-108; А. Ассман, Я. Ассман, День вчерашний в дне сегодняшнем. Средства массовой информачии и сочиальная память, „Уроки истории XX века” 24 XII 2012, [online] http://www.urokiistorii.ru/memory/research/51658, 21 III 2014.

16 Por. A. Assmann, Memory, Individual and Collective, [w:] The Oxford Handbook of Contextual Political Analysis, red. R. E. Goodin, Ch. Tilly, New York 2006, s. 210-226.

17 Tamże.

18 A. Assmann, Memory, Individual and Collective..., s. 210-226; А. Ассман, Трансформации нового режима времени, „Новое миетарурное обозрение” 2012, nr 116, [online] http://magazines.russ. ru/nlo/2012/116/a4-pr.html, 21 III 2014.

19 А. Ассман, Трансформачии нового режима времени... 
Kosellecka. Idee o czasowych wewnętrznych strukturach pojęc ${ }^{20}$, określających ewolucję semantycznej zawartości tekstów i specyfikę oczekiwań społecznych, formułowane przez lidera intelektualnego tego kierunku naukowego są dosyć komplementarne z wyznaczoną przez Aleidę Assmann strategią badania symbolicznych struktur pamięci społecznej. To właśnie struktury pamięci społecznej są, w naszej ocenie, swego rodzaju symbolicznymi granicami, pewnym wirtualnym „rezerwuarem” pojawiających się sensów. Struktury te określają czasowość konceptów społecznych, które odzwierciedlają oczekiwania ludzi, opisują destrukcję/pojawienie się nowych tożsamości i ich instytucjonalny design, orientując uczestników komunikacji na „teraźniejszość”, „przeszłość” bądź „przyszłość”.

Podsumowując i interpretując teoretyczne dziedzictwo badaczy niemieckich, „osłabiamy” ich metodologiczne akcenty w opisie funkcjonowania „pamięci kulturowej” pojmowanej jako „nadanie trwałości”, „powtarzalności”, pojawiających się stereotypów kulturowych i tożsamości. Ponieważ, naszym zdaniem, ogranicza to możliwości badania współczesnych form pamięci społecznej, które są w swojej dynamice bliższe konceptualizacji kultury jako historycznej formy „pamięci mobilnej” łączącej tożsamości przeszłości z tożsamościami teraźniejszości dla uprzedzenia przyszłego komunikowania $\operatorname{się~}^{21}$. I odwrotnie - wzmacniamy właściwą ich wizji czasowej dynamiki pamięci refleksję o pamięci jako symbolicznym „organie diachronii”, urzeczywistniającym „rozciągnięcie w czasie” poprzez generowanie różnic. W ujęciu swoistości metodologii „komunikacyjnych” strategii badania pamięci społecznej autor kieruje się intelektualnymi intencjami przedstawionymi w koncepcjach Talcotta Parsonsa, Jürgena Habermasa, Anthony'ego Giddensa, Pierre'a Bourdieu, nadając priorytet pojęciowemu instrumentarium Niklasa Luhmanna (a spośród rosyjskich autorów - Aleksandra Filippowa $)^{22}$. Dla ewolucji systemów społecznych, jak uważa Luhmann, fundamentalne znaczenie ma równowaga w postrzeganiu przez uczestników interakcji społecznych statości zmian. U podstaw podobnej synchronizacji postrzegania przez aktorów społecznych leży semantyczna procedura typizacji powtarzających się wydarzeń, liczenia czasu, które zależy od mniej lub bardziej stypizowanych, powtarzajacych się wydarzeń ich historii systemowej. [...] Historia systemowa, wspólnie przeżywana i wspominana, stanowi istotna przestankę zrozumienia i nie da sie jej zastąpić obiektywnie ustalona historia świata ${ }^{23}$. Kiedy historia nabiera znaczenia, staje się jednocześnie bardziej umowną, staje się jednocześnie pamięcią i zapomnieniem ${ }^{24}$. Od możliwości komunikatyw-

20 Рог. Р. Коземлек, К вопросу о темпоральных структурах в историческом развитии понятий, [w:] История понятий, история дискурса, история менталитета. Сб. статей, red. Х. Э. БёАекер, przekład z niem., Москва 2010, s. 21-33.

21 Н. Ауман, Эволючия, Москва 2005, s. 195-209.

22 Por. nр.: Н. Ауман, Введение в системную теорию, Москва 2007; А. Ф. Филиппов, Соииология пространства, Санкт-Петербург 2008.

23 Н. Ауман, Мировое время и история систем. Об отномениях между временными горизонтами и социальными структурами общественных систем, Москва 2004, nr 5 (44), s. 131-168.

24

Tamże. 
nych tego rodzaju równowagi zdarzeń przeszłości i teraźniejszości zależy ewolucja lub inwolucja współczesnego systemu społecznego ${ }^{25}$.

Podobna konceptualizacja fenomenu „pamięci politycznej” jest swego rodzaju operacjonalizacją ogólnego teoretycznego ukierunkowania na badanie procesów kulturowych, zaznaczonego w pracach uznanego przedstawiciela współczesnej „socjologii kulturowej" (cultural sociology) Jeffreya C. Alexandra. Badacz podkreślił, że w większości tradycyjnych modeli socjologii kultury wymiary kulturowe nie stanowią niezależnych zmiennych, lecz są pochodną bardziej „trwałych” zmiennych struktur społecznych. „Mocny program” (strong program) badań fenomenów kulturowych powinien opierać się na analizie kognitywnej symbolicznych struktur sieci sensów, w odróżnieniu od „słabych programów”, gdzie opisy wartości, norm, ideologii często są pochodną zinstytucjonalizowanego porządku lub są redukowane do pojedynczych zjawisk społecznych i psychologicznych ${ }^{26}$. Potrzeba „mocnego programu” teorii pamięci politycznej zakłada zmianę priorytetów w strategiach badawczych: przejście od poszukiwania obiektywnych lub subiektywnych podstaw procesu kulturowo-historycznego i od opisu tożsamości do rozumienia ich natury komunikacyjnej, symbolicznej.

To teoretyczne założenie o związku legitymizacji porządku społecznego i „ukrytych wzorców" kultury oraz o znaczeniu tego związku dla funkcjonowania politycznego podsystemu społeczeństwa uzasadnił swego czasu Talcott Parsons, który zauważył, że w ewolucji społeczeństwa kluczową rolę odgrywa system kulturowy. Korelacja z nim nadaje znaczenie zinstytucjonalizowanemu porządkowi społecznemu. W procesie legitymizacji wzorce kulturowe poprzez specjalny system symboli pozwalają uzasadnić tożsamość. Natomiast legitymizacja polityczna jako „dominująca interpretacja” standardów normatywnych pełni szczególną funkcję w systemie legitymizacji całego społeczeństwa ${ }^{27}$. Jednocześnie, konceptualizacja komunikacyjnej i znaczeniowej relacji wzajemnej kultury, legitymizacji i władzy w teorii T. Parsonsa nosi znamiona „słabego programu" badań nad rolą i miejscem symbolicznych wymiarów dynamiki społeczno-kulturowej. Bardziej obiecujący dla „wzmocnienia” programu badań wydaje się opis władzy politycznej jako pośrednika symbolicznego, którego schematy legitymizujące, oparte na korelacji sity i przemocy ${ }^{28}$, określają specyfikę pamięci politycznej i jej formy ewolucyjnej - kultury politycznej, o czym wspomniano wcześniej.

Opisanie „struktur pamięci politycznej” oznacza odnalezienie symbolicznych schematów („ukrytych wzorców”) typizacji, strukturyzowania przedmiotowych, społecznych i czasowych granic władzy publicznej, charakterystycznych dla poszczególnych społeczności. Przy tym zaufanie polityczne i legitymizacja polityczna pojmowana jako „internacjonalizacja” symbolicznie ukształtowanych struktur oczekiwań politycznych

25 Н. Ауман, Эволюиия..., s. 54.

26 J. C. Alexander, The meanings of social life: a cultural sociology, New York 2003, s. 11-26; J. C. Alexander, Clifford Geertz and the Strong Program: The Human Sciences and Cultural Sociology, "Cultural Sociology" 2008, Vol. 2 (2), s. 157-168.

27 Т. Парсонс, Понятие общества: компоненты и их взаимоотношения, t. 1, wуd. 2, Москва 1993, s. $94-122$.

28 Н. Ауман, Bласть, Москва 2001, s. 102. 
do komunikacji władzy stanowi główne ogniwo kształtowania struktur pamięci politycznej. Pamięć polityczna zapewnia synchronizację oczekiwań politycznych przede wszystkim na podstawie uczasowienia strukturalnej współzależności między legitymizacją a przemocą, jej symbolizacji w ciągach wydarzeń z teraźniejszości ku przeszłości i przyszłości. Przy tym, podążając za intelektualnymi intencjami Teuna A. van Dijka, swoistość „polityki pamięci” można rozpatrywać jako specyficzny wariant wykorzystania władzy symbolicznej (i odpowiednio: polityki symbolicznej) i należy je wiązać z aktywnością elit władzy w kwestii zarządzania i kontroli dostępu innych grup do dyskursu publicznego. Władza tego rodzaju jest realizowana dzięki posiadanemu przez owe grupy kapitałowi symbolicznemu, wykorzystywanemu przez nie do społecznego konstruowania i wsparcia struktur dyskursywnych, co zapewnia im dominację polityczną poprzez kontrolę nad świadomościa audytorium ${ }^{29}$. Tym samym badanie pamięci politycznej i polityka pamięci muszą odpowiedzieć na pytanie: kto i w jaki sposób sprawuje kontrolę nad dyskursem publicznym we wszystkich jego różnorodnych przejawach semiotycznych, kogo i w jaki sposób wyklucza się z procesu publicznej reprezentacji na różnych poziomach współdziałania społecznego ${ }^{30}$.

U podstaw bazowych ciągów zdarzeń (kompleksów znaczeniowych) pamięci politycznej leżą wydarzenia w różny sposób związane z semantyką „wiktymizacji”, jej przezwyciężeniem lub oczekiwaniem (wojny, rewolucje, represje, ludobójstwo), a „symbole" władzy zawsze przypominają o możliwej przemocy i przymusie. W związku z tym odwołań do tragicznych wydarzeń z przeszłości stanowiących także przykłady ich bohaterskiego przezwyciężenia nie należy w żadnym razie traktować jako rudymentów lub „cieni”. Struktur pamięci politycznej nie da się sprowadzić do podobnych projekcji symbolicznych, ale są one dla nich bazowe. Kody władzy, schematy jej legitymizacji, jak słusznie uważa Niklas Luhmann, są skoordynowane z praktykami przemocy, ponieważ legitymizacja ma za zadanie zabezpieczenie przed dowolnym wykorzystaniem przemocy. Przemoc może być zaprezentowana jako przeszłe lub przyszłe wydarzenie, którego można uniknąć we współczesności, ponieważ warunki jej zastosowania są znane. Inna sprawa, że specyfika strukturyzowania i symbolizacji takich praktyk legitymizacji zależy od stopnia ztożoności politycznego mechanizmu wtadzy i jego dostępności dla cztonków spoteczeństwa ${ }^{31}$.

Zarysowane przesłanki metodologiczne badania semantycznych struktur pamięci politycznej, zdaniem autora niniejszego artykułu, otwierają nowe horyzonty teoretyczne dla interpretacji swoistości polityki pamięci jako specyficznej polityki symbolicznej i praktyki politycznej legitymizacji porządku społecznego w przestrzeni postradzieckiej. Istniejące sposoby konceptualizacji „polityki pamięci” w społeczeństwach postradzieckich w różny sposób „obciążone” są metodologicznymi aporiami, charakterystycznymi dla opisu natury społecznej, a w szczególności pamięci politycznej. Tak więc, dla części przedstawicieli nauk historycznych swoiste jest przeciwstawianie badania „po-

29 Т. А. Аейк, Аискурс и власть..., s. 32.

30 T. A. Dijk, Discourse and Power, New York 2008, s. 14.

31 Н. Ауман, Власть..., s. 102-151. 
lityki historycznej” - badaniu „polityki przeszłości” i „polityki pamięci”. Przy tym, jeśli polityka pamięci i związane z tym upolitycznienie historii są postrzegane jako swego rodzaju naturalny atrybut ewolucji społecznej wszystkich złożonych społeczeństw, to polityka historyczna, jako świadome działanie, realizowane za pośrednictwem specjalnych instytucji państwowych („instytutów pamięci narodowej”) i prawodawstwa z udziałem historyków jako ekspertów, uważana jest za indoktrynację polityczną i stanowi stosunkowo nowe zjawisko. Jak sądzą badacze „polityki historycznej” i praktyk tworzenia „prawnych regulacji pamiętania”, fenomen tego rodzaju stanowi sposób samolegitymizacji oportunistycznych elit postradzieckich, generujących zjawisko „kryminalizacji” i „wiktymizacji” wiedzy historycznej w mniej lub bardziej pluralistycznych społeczeństwach będących w trakcie przemian demokratycznych ${ }^{32}$.

W badaniach ukierunkowanych socjologicznie polityka pamięci jawi się jako symboliczna praktyka konstruowania tożsamości narodowej („symboli tożsamości”). W roli symboli politycznych mogą występować nacechowane semantyką władzy obiekty, określające i organizujące działania w przestrzeni politycznej, systematyzujące je w strukturze „poziomej” lub „pionowej”. Zaznacza się, że symbole mogą należeć do różnych planów czasowych zjawisk i działań politycznych, „odsyłając do przeszłości, teraźniejszości lub przyszłości, do początku lub końca, przełomu lub powrotu, więc odpowiednio - charakteryzując te bądź inne zdarzenia w kategoriach tworzenia lub zniszczenia, chaosu lub porządku" ${ }^{33}$.

Przy ogólnej zgodzie co do zasadności i heurystyczności tego rodzaju strategii badawczych polityki pamięci, należy zauważyć, iż wnioski na temat tego, że „odrzucenie” symboli przemian i „potrzeba symboli powrotu” są głównym źródłem niepowodzeń komunikacyjnych na drodze instytucjonalizacji wartości demokratycznych, wydają się powierzchowne i zideologizowane. Te same preferencje wartości i norm oraz fakty historyczne w zależności od systemu czasowego mogą nabierać różnego potencjału ewolucyjnego. Jak już wspomniano, u podstaw wszystkich symbolicznych schematów politycznej legitymizacji leży symbolizacja „praktyk przymusu” i „heroicznej ofiarności”, lecz w zależności od semantycznych wektorów uczasowienia i zróżnicowania komunikacji politycznej mogą one nabierać „ludzkiego” lub „nieludzkiego” charakteru. W tym kontekście symbolizacja w teraźniejszości niedawnego doświadczenia socjalistycznej przeszłości sama w sobie jest pod względem wartościowania neutralna i może być zarówno źródłem innowacji, jak i degradacji komunikacyjnej, w zależności od horyzontu czasowego planowania kursu politycznego.

Operacjonalizować takie nastawienie metodologiczne, jak sądzi autor, pozwala model teoretyczny „fal pamięci” zaproponowany przez rosyjskiego politologa Michaiła Iljina, który w różny sposób odwołuje się do współczesnych badań nad swoistością czasu

32 Por. np.: А. Мимкер, Россия: власть и история, „Pro et Contra (Историческая политика)” 2009 , t. 13, nr 3-4 (46), s. 6-23; Н. Копосов, Память строгого режима: История и политика в России, Москва 2011.

33 Б. Аубин, Символьь возврата вместо символов перемен, „Pro et Contra (Авадцать мет без советской власти)" 2011, t. 15, nr 5 (53), s. 6-22. 
społecznego i politycznego ${ }^{34}$. Zgodnie z jego teoretycznymi intencjami kształtowanie pamięci politycznej można przedstawić jako formowanie pewnego sensownego szeregu działań, zdarzeń lub stanów, gdzie fale pamięci to schematy rytmicznej organizacji, typizacji wydarzeń politycznych, przyktadów ich faktycznej realizacji, scenariuszy rozwoju, programów reprodukcji systemów politycznych. Polityka pamięci to uzasadnienie „przeszłych”, „teraźniejszych” i „przyszłych” scenariuszy kursu politycznego, które są swego rodzaju rytmicznymi programami możliwego i/lub pożądanego biegu wydarzeń politycznych. Jednak nie wszystkie scenariusze sprzyjają czasowej strukturyzacji i nie wszystkie odpowiadają perspektywicznym wektorom ewolucji rzeczywistości politycznej.

Znamienna w tym kontekście jest sprzeczność praktyk pamięci politycznej charakterystycznych dla szeregu państw postradzieckich. Jednym z rozprzestrzenionych „scenariuszy" politycznej legitymizacji strukturyzowania pamięci politycznej w nowych krajach jest uczasowienie polityki symbolicznej „etnicznego ludobójstwa”. Za tego rodzaju dyskursem polityki pamięci wyraźnie widać symboliczną politykę dekonstrukcji ciągu temporalnego pamięci politycznej, opartego na typizacji wydarzeń ofiarności i poświęcenia uczestników rewolucji socjalistycznej, Wojny Ojczyźnianej, heroizmu „obrońców i budowniczych socjalizmu”.

Etnizacja przemocy politycznej, wyprowadzona poza horyzont czasu historycznego i przedstawiona jako absolutne, mityczne lub teologiczne wydarzenie „stawania się narodu", staje się sposobem dekonstrukcji struktur pamięci politycznej okresu budowania socjalizmu. Podstawą takich praktyk symbolicznych jest procedura semantycznego utożsamienia wydarzeń związanych z przemocą z "odległej” i „niedawnej przeszłości” (ofiary etnicznych przodków w imię „Ojczyzny”, przemoc komunistyczna i nazistowska, „polityka asymilacji”, „władza rad”) dla konstruowania scenariuszy przyszłego „wejścia” do przestrzeni europejskiej pamięci społecznej „tolerancji i zgody”. Tego rodzaju rekonstrukcja symboliczna oczekiwań politycznych, na pierwszy rzut oka, może prowadzić do ukształtowania struktur tożsamości narodowej, europejskiej, co widać w niektórych krajach.

Jednocześnie etnizacja wydarzeń pamięci politycznej przy strukturyzowaniu oczekiwań politycznych w większości krajów byłego Związku Radzieckiego nie doprowadziła do ukonstytuowania się pamięci narodowej, lecz odtwarza sprzeczności w scenariuszach czasu politycznego i wspiera istniejące polityczne rozłamy w tożsamościach. Potwierdzeniem tego mogą być wydarzenia na Ukrainie, gdzie dążenie nowych elit symbolicznych do wyparcia „dyskursu radzieckości” doprowadziło nie tyle do powstawania tożsamości obywatelskiej, ile do zredukowania jej do symboliki archaicznych, lokalnych sposobów kontroli ideologicznej, generujących wciąż nowe podziały i idealizujących przypadki przemocy etnopolitycznej.

W niejednorodnych pod względem etnicznym przestrzeniach politycznych tego rodzaju temporalizacja etniczności, używając metafory informatycznej, nie tworzy in-

34 М. В. ИАьин, Волны памяти versus сюжеть развития, „Политические исследования” 2002, nr 4, s. 31-59. 
terfejsu, stanu korelacji między programami pamięci politycznej. Dążenie do wykorzystania czasowego programowania regionalnej tożsamości politycznej na podstawie typizacji wydarzeń przemocy etnicznej jako symbolicznego zasobu narodowej identyfikacji staje się przeszkodą dla konstytuowania narodowej pamięci politycznej. Pojawiająca się przy tym symbolizacja mitycznego uzasadnienia wrogości w procesie politycznej legitymizacji zawsze jest przekształcana w działania przemocy ${ }^{35}$. Zdaniem autora niniejszego artykułu ignorowanie biegu zdarzeń pamięci politycznej, „wydarzeń rewolucji" (stanowiących ważne ogniwo w konstytuowaniu każdej pamięci narodowej wobec „wyjątkowości” symbolicznych obrazów ofiary), przy braku pozytywnego konstruowania wydarzeń „nowej rewolucji” nieuchronnie zawęża operacyjny repertuar interpretacji historycznych, „scenariuszy” rytmicznej organizacji przestrzeni politycznej ${ }^{36}$. W związku z tym należy pamiętać, że bez odpowiedniej strategii uczasowienia wydarzeń politycznych zawsze istnieje ryzyko, że zamiast spotecznie oczekiwanej trwatości ${ }^{37}$ nastąpi zawężenie scenariuszy politycznych teraźniejszości, a tym samym - horyzontów planowania politycznego. Odsyła to do teoretycznych propozycji znanego badacza symbolicznych wymiarów procesu komunikacji Niklasa Luhmanna, który podkreślał, że historia może konstytuować się tylko w czasie, jako szczególnym wymiarze sensu i nie powinna pozostawać historia faktycznej sekwencji wydarzeń, gdzie teraźniejszość jest rozumiana jako rezultat dziatań przesztych i przysztych ${ }^{38}$. Właśnie „usensowiona historia” zapewnia swobodny dostęp do sensu przesztych i przysztych zdarzeñ ${ }^{39}$, otwierając możliwości kontrolowania społecznego konstruowania czasu politycznego poprzez politykę symboliczną.

Tak więc bardziej produktywna dla socjologicznego i politycznego opisu „pamięci politycznej” i „polityki pamięci” jest artykulacja dyskursywnych struktur oczekiwań politycznych (czasowych struktur oczekiwań politycznych) w społeczeństwie i ich form symbolicznych, gdzie to, co symboliczne, zastępując „wielość” wydarzeń politycznych, stanowi ich „zarchiwizowaną" prezentację. Decydującą rolę w tego rodzaju budowaniu struktury wydarzeń politycznych (kompleksów znaczeniowych) odgrywa symboliczne konstruowanie „systemu czasowego” komunikacji politycznej, gdzie „pamięć systemu politycznego", jako dynamiczna relacja zwrotna symbolicznych schematów retrospekcji i projekcji wydarzeń politycznych, stanowi swego rodzaju symboliczne jądro. Temporalna składowa „symbolicznej polityki pamięci” manifestuje się w semantycznych praktykach tworzenia, podtrzymania lub niszczenia podobnych projekcji, a co za tym idzie dynamiki tożsamości politycznych i dyskursów politycznej dominacji elit społecznych.

35 S. J. Kaufman, Symbolic Politics or Rational Choice? Testing Theories of Extreme Ethnic Violence, „International Security” 2006, Vol. 30, nr 4, s. 81.

О. Малинова, Тема промлого в риторике президентов России, „Pro et Contra (Политические системы постсоветских стран)" 2011, nr 3-4 (52), s. 119.

37 Por. П. Штомпка, Социология. Анализ современного общества, przeł. С. М. Червонной, Москва 2005, s. 505. (Termin za polskim wydaniem: P. Sztompka, Socjologia. Analiza spoteczeństwa. Nowe poszerzone wydanie, Kraków 2012, s. 544 [uwaga Redakcji]).

38 Н. Ауман, Социальные системь.. Очерк общей теории, Санкт-Петербург 2007, s. 122.

39 Tamże. 
Zaprezentowane możliwości metodologiczne badania temporalnych wymiarów polityki symbolicznej pozostawiają wiele niewypełnionych i niewyjaśnionych teoretycznie luk związanych z: koncepcyjną kompatybilnością teorii pamięci politycznej oraz teorii kultury politycznej i legitymizacji politycznej; z podstawami typologizacji systemów czasowych pamięci politycznej i charakteru ich relacji, ze swoistością znaczenia treści podstawowych wydarzeń politycznych, wreszcie - z priorytetami w wyborze strategii analizy dyskursu do opisu struktur i obiektów symbolizacji politycznej. Osobny problem stanowi badanie systemu temporalnego polityki symbolicznej w warunkach globalizującego się świata, w którym zmienia się charakter reprodukcji „polityczności”, a komunikacja sieciowa prowadzi do defragmentacji pamięci narodowej.

Strategia ta pozwala, z jednej strony, przezwyciężyć normatywizm i aksjologizm właściwy bardziej tradycyjnym interpretacjom fenomenów symbolicznych w opisie ich wpływu na procesy społeczne we współczesnym społeczeństwie, a z drugiej - pokonać trudności zrozumienia roli składowej temporalnej w polityce symbolicznej jako pewnej „zależnej” od przestrzennych i technologicznych parametrów komunikacji społecznej, wyraźniej określić „,niezależność”, względną autonomię struktur czasowych w dynamice symbolicznej. Na podstawie określenia czasowych „ram” pamięci politycznej można bardziej kompleksowo wykorzystać istniejące już metody strukturyzacji, klasyfikacji, analizy treści form symbolicznych i praktyk polityki symbolicznej.

Należy uznać, że obecne zakłócenia komunikacyjne w procesie politycznym w krajach postradzieckich są w znacznym stopniu uwarunkowane przez semantyczne ubóstwo sposobów typizacji szeregów wydarzeń politycznych niedawnej przeszłości, brak ustrukturyzowania zdarzeniowych ciągów oczekiwań politycznych z „teraźniejszości” do „przeszłości” i „przyszłości”, odtwarzanie archaicznych schematów politycznej legitymizacji poprzez radykalną i koniunkturalną ideologizację. To nieuchronnie prowadzi do wojny „polityk pamięci”, która trwa nieprzerwanie od dwóch dekad, zarówno w wewnętrznych przestrzeniach komunikacyjnych nowych krajów, jak i pomiędzy nimi. Jednocześnie, parafrazując Manuela Castellsa, pozostaje mieć nadzieję, że „nie istnieje nic takiego, co nie może zostać zmienione" przez dostarczenie informacji, wsparte legitymizacją kultury politycznej, która jest rekonstruowana z doświadczenia solidarnego istnienia w „przeszłości” i możliwej „przyszłości” z punktu widzenia „teraźniejszości”.

Tłumaczenie: Magdalena Romanowska

\section{BIBLIOGRAFIA}

Ассман А., Ассман Я., День вчерачиий в дне сегодняминем. Средства массовой информаиии и сочиальная память, „Уроки истории XX века”, 24 XII 2012, [online] http://www.urokiistorii.ru/memory/research/51658.

Ассман А., Трансформащии нового режима времени, „НАО” 2012, nr 116, [online] http:// magazines.russ.ru/nlo/2012/116/a4-pr.html. 
Ассман Я., Культурная память: Письмо, память о прочлом и политическая идентичность в высоких культурах древности, przeł. М. М. Сокольской, Москва 2004.

Аейк Т. А., Аискурс и власть: Репрезентачия доминирования в языке и коммуникации, prze$\mathrm{kład} \mathrm{z} \mathrm{ang.,} \mathrm{Москва} 2013$.

Аубин Б., Символьь возврата вместо символов перемен, „Pro et Contra (Авадцать мет без советской власти)” 2011, t. 15, nr 5 (53).

Ильин М. В., Волнь памяти versus сюжеть развития, „Политические исследования” 2002, $\mathrm{nr} 4$.

История и память: историческал культура Европь до начала Нового времени, red. А. П. Репина, Москва 2006.

Козельек Р., К вопросу о темпоральньц структурах в историческом развитии понятий, [w:] История понятий, история дискурса, история менталитета, red. Х. Э. Бёдекер, przekład z niem., Москва 2010.

Копосов Н., Память строгого режима: История и политика в России, Москва 2011.

Ауман Н., Введение в системную теорию, Москва 2007.

Ауман Н., Власть, Москва 2001.

Ауман Н., Мировое время и история систем. Оботноменияхмежду временными горизонтами и социальными структурами общественных систем, „Аогос” 2004, nr 5 (44).

Ауман Н., Социальньце системь. Очерк общей теории, Санкт-Петербуг 2007.

Ауман Н., Эволюиия, Москва 2005.

Малинова О., Тема прошилого в риторике президентов России, „Pro et Contra (Политические системы постсоветских стран)” 2011, nr 3-4 (52).

Маркс К., 18 брюмера Ауи Бонапарта, [w:] К. Маркс, Ф. Энгельс, Сочинения, t. 16, Москва 1960.

Миялер А., Россия: власть и история, „Pro et Contra (Историческая политика)” 2009, t. 13, nr 3-4 (46).

Мегим А., Историческал эпистемология, Москва 2007.

Нора П., Между памятью и историей. Проблематика мест памяти, [w:] П. Нора i in., Франиия-память, Санкт-Петербург 1999.

Парсонс Т., Понятие общества: компоненты и их взаимоотномения, Москва 1993, t. 1, wyd. 2.

Репина $\Lambda$. П., Концепции социальной памяти в современной историографии, [w:] Феномен прошлого, red. И. М. Савельева, А. В. Полетаев, Москва 2005.

Репина $\Lambda$. П., Культурная память и проблемь историописания, Москва 2003.

Савельева И. М., Полетаев А. В., Знание о прошлом: теория и история, t. 2, Санкт-Петербург 2006.

Сартр Ж.-П., Мертвыце без погребения. Аьявол и Господь Бог, Москва 2015.

Штомпка П., Социология. Анализ современного, przeł. С. М. Червонной, Москва 2005.

Фикиппов А. Ф., Социология пространства, Санкт-Петербург 2008.

Alexander J. C., The meanings of social life: a cultural sociology, New York 2003.

Alexander J. C., Clifford Geertz and the Strong Program: The Human Sciences and Cultural Sociology, „Cultural Sociology” 2008, Vol. 2 (2).

Assmann A., Canon and Archive, [w:] Cultural Memory Studies: An International and Interdisciplinary Handbook, red. A. Erll, A. Nünning, S.B. Young, Berlin-New York 2010. 
Assmann J., Communicative and Cultural Memory, [w:] Cultural Memory Studies: An International and Interdisciplinary Handbook, red. A. Erll, A. Nünning, S.B. Young, Berlin-New York 2010.

Assmann A., Memory, Individual and Collective, [w:] The Oxford Handbook of Contextual Political Analysis, red. R.E. Goodin, Ch. Tilly, New York 2006.

Castells M., Materials for an exploratory theory of network society, „British Journal of Sociology” 2000, Vol. 51, nr 1 .

Dijk T. A., Discourse and Power, New York 2010.

Kaufman S. J., Symbolic Politics or Rational Choice? Testing Theories of Extreme Ethnic Violence, „International Security” 2006, Vol. 30, nr 4.

Sartre J.-P., Diabet i Pan Bóg, przeł. J. Kott, „Dialog” 1959, nr 9.

Sztompka P., Socjologia. Analiza spoteczeństwa. Nowe poszerzone wydanie, Kraków 2012.

Konstantin Fiodorowicz ZAWIERSZYNSKIJ - doktor habilitowany nauk politycznych, profesor w Katedrze Teorii i Filozofii Polityki na Wydziale Politologii Petersburskiego Uniwersytetu Państwowego. 